\title{
FAMILIAL PITRESSIN-RESISTANT DIABETES INSIPIDUS WITH MENTAL DEFECT
}

\author{
BY
B. H. KIRMAN, J. A. BLACK, R. H. WILKINSON and P. R. EVANS
From The Hospital for Sick Children, Great Ormond Street, the Fountain Hospital, Tooting, and Guy's Hospital, London

(RECEIVED FOR PUBLICATION JULY 22, 1955)

Diabetes insipidus resistant to the injection of antidiuretic hormone (pitressin or A.D.H.) is a rare disease which during the past 10 years has been recognized to be different from classical diabetes insipidus. Warkany and Mitchell (1939) reviewed hereditary diabetes insipidus but made no clear distinction between hypothalamo-pituitary and renal cases. Some of the early cases were found to be pitressin-resistant, e.g., those of Bailey and Bremer (1921), but the separate nature of the conditions was not clearly shown until 1945, when Waring, Kajdi and Tappan described

'six children with the following features: onset after birth, erratic and unexplained fever, persistent constipation, vomiting in the first three months of life, polydipsia and polyuria not responsive to pitressin, high values for serum sodium and chloride, high skin resistance, rapid dehydration if fluids are restricted or withheld, inability to excrete urine of high specific gravity, familial incidence and occurrence in boys only'.

Their paper admirably summarizes the essential features and avoids confusion with ordinary diabetes insipidus by being entitled 'A Congenital Defect of Water Metabolism'. We report here another family containing children with the same disorder, associated with mental defect.

\section{Family History}

The remote family history is scanty, but a maternal great-grandmother of our patients was said to be mentally backward and eventually developed depression and entered a mental hospital. Her husband was said to have suffered from a condition resembling diabetes insipidus and to have died at the age of 40 . Of their 13 children, only three survived infancy. One was the grandmother of our patients; her daughter married the father who was healthy and was 22 years older than his wife. He was $\mathrm{Rh}$ positive, she was $\mathrm{Rh}$ negative, and the second, third and fourth children were $R h$ positive (Table 1). During the fourth pregnancy her blood was found to contain D antibodies but none of the children had clinical signs of erythroblastosis foetalis, nor did necropsy on the fifth child, who died 24 hours after birth, show evidence of it.

\section{The Children}

Case 1. The first child (G.C.) was a boy who died in The Hospital for Sick Children at 18 months. At 6 months he had failed to gain weight and lacked appetite; he weighed only $10 \mathrm{lb}$. when he died, his maximum weight having been $14 \mathrm{lb} .6 \mathrm{oz}$. He was admitted on account of malnutrition. He was thin and pale, with prominent costochondral junctions. The specific gravity of his urine was not tested, but the urine was not found to be abnormal by routine tests. He was noticed to 'pass water well'. The blood urea, on a single estimation, was $40 \mathrm{mg} . \%$. He became dehydrated and was given intravenous fluids after which oedema developed. There was no diarrhoea, but his stools were said to be large and fatty with a total fat content of $44 \%$ of dried faeces (on a largely milk diet). Finally he developed mastoiditis and died in spite of mastoidectomy. At necropsy, small subarachnoid and subdural haemorrhages were found, but no abnormality of the kidneys was noted, though they were stated to be pale and flabby.

TABLE 1

BLOOD GROUPS OF FAMILY

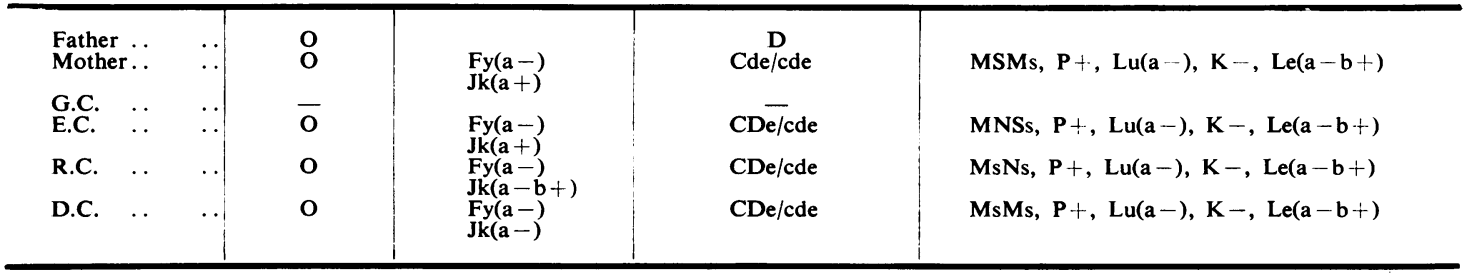


Case 2. The second child (E.C.), another boy, also suffered from a wasting disease, and was eventually found to be a case of pitressin-resistant diabetes insipidus.

Pregnancy, birth and the neonatal period were normal. He weighed $8 \mathrm{lb} .14 \mathrm{oz}$. at birth and was breast fed until he was 4 months old, when he weighed $12 \mathrm{lb}$. Then he was bottle fed and failed to gain weight; at 6 months he was admitted to The Hospital for Sick Children on account of failure to thrive, constipation and refusal of feeds. He was small, thin and dehydrated; in his case too the costochondral junctions were enlarged. The cerebrospinal fluid was normal apart from a chloride content of $850 \mathrm{mg}$. \% (as $\mathrm{NaCl}$ ).

He weighed $13 \mathrm{lb}$. at 9 months and $18 \mathrm{lb}$. at 16 months. At 21 months he still had cough, vomiting, anorexia, constipation and lethargy. A barium swallow, urine examination and blood count were all normal. Three months later he had a severe upper respiratory infection with a normal blood count and chest radiograph, and a negative tuberculin test (Mantoux 1/1,000). His duodenal juice contained a normal amount of trypsin. The blood sedimentation rate was $52 \mathrm{~mm}$. in one hour (normal, up to 10), and there was a trace of albumin in the urine. After treatment he weighed $18 \mathrm{lb}$. There was another respiratory infection at $2 \frac{1}{2}$ years, when he weighed $19 \mathrm{lb}$. When nearly 3 years old he broke his left tibia, and at 4 years was admitted to Guy's Hospital with a fractured femur. Between the ages of 3 and 4 years he had some attacks which were thought to be faints. This was his fifth hospital admission, and only then was polydipsia noticed; polyuria was still not obvious as he was incontinent. Attempts to restrain him in order to collect a specimen of urine caused fever, presumably because he stopped drinking, but this was not understood at the time. Blood examination showed a hyperelectrolytaemia. He was obviously mentally defective; he could not talk or feed himself and had not walked without support.

He was in much the same state when re-admitted to The Hospital for Sick Children for investigation at 4 years and 5 months. This admission was prompted by the findings of hyperelectrolytaemia and resistance to pitressin in his younger brother (D.C.). He was transferred to the Fountain Hospital after investigation and confirmation of the diagnosis.

He was an imbecile. He stood with difficulty, holding on for support. He could not feed himself with a spoon or bread and butter, but would hold a cup. He did not talk or dress himself. He saw and heard. He was doubly incontinent. He obeyed simple instructions. On the Vineland Social Maturity Scale his developmental quotient was 31. On the Merrill Palmer Scale his intelligence quotient was 37 . He was obviously craving for fluid and cried until this want was supplied, avidly seizing a glass and draining it. On one occasion he drank four glasses full of water in rapid successionapproximately a litre. No epileptic attacks occurred whilst in hospital.

Physically he was in poor general health with a striking generalized pallor, thin, listless, with marked infantilism and hypotonia but no specific neurological abnormalities. He had purulent rhinorrhoea and intermittent low pyrexia. He had several attacks of pneumonia, otitis media and enteritis. He rarely remained well for more than a few weeks. The skull circumference was $18 \frac{1}{2}$ in. The ocular fundi appeared normal. The blood Wassermann reaction, Kahn and Meinicke tests were negative.

Two years later the intelligence quotient (Merrill Palmer) was unchanged; he could walk and run and could form short sentences. The electroencephalogram was within normal limits.

The following investigations were carried out on E.C.

RADIOGRAPHS. When aged 4 years the long bones were slender, the femora and tibiae were slightly bent, as in fragilitas ossium, but rickets was not present. The rib ends were expanded a little but not abnormally. There was a fracture of the femur. The skull was normal and the pituitary fossa was well formed. Bone age and ascending pyelography were normal.

BLOOD Chemistry. When the child was aged 4 years 5 months the blood chemistry was: blood urea $52 \mathrm{mg}$. per $100 \mathrm{ml}$., serum sodium $150 \mathrm{~m} . E q . / 1 .$, serum potassium $5.0 \mathrm{~m} . \mathrm{Eq} . / \mathrm{l}$, plasma chlorides $109 \mathrm{~m} . \mathrm{Eq} . / \mathrm{l}$, plasma bicarbonate $27.9 \mathrm{~m} . \mathrm{Eq} . / \mathrm{l}$.

URINE. Urine examination showed no abnormality except for a trace of protein, and a specific gravity of 1,004 after 12 hours' fluid restriction. The amino-acid excretion was normal and no phenyl pyruvic acid was found.

Pitressin Tests. Two tests were carried out, the first with a dose $=0.25$ units at 4 p.m. when the blood urea level was $31 \mathrm{mg}$. $\%$, the second after a dose $=2.5$ units at 12 noon.

First pitressin test

\begin{tabular}{c|c|c|c|c|c}
\hline Time & S.G. & $\begin{array}{c}\text { Volume } \\
\text { (ml.) }\end{array}$ & $\begin{array}{c}\text { Urea Clearance } \\
\text { (\% average normal) }\end{array}$ & $\begin{array}{c}\text { Chloride Concentration } \\
\text { (m.Eq./1.) }\end{array}$ & $\begin{array}{c}\text { Chlorides/Hour } \\
(\mathrm{m} . \mathrm{Eq} .)\end{array}$ \\
\hline 3-4 p.m. & 1,004 & 89 & 76 & $15 \cdot 6$ & 14.5 \\
4-5 p.m. & 1,003 & 116 & $65 \cdot 5$ & $1 \cdot 39$ \\
5-6 p.m. & 1,003 & 106 & $68 \cdot 5$ & 1.53 \\
$6-7$ p.m. & 1,005 & 81 & $71 \cdot 7$ & $15 \cdot 6$ & $1 \cdot 58$ \\
\hline
\end{tabular}

Second pitressin test

\begin{tabular}{c|c|c|c|c}
\hline Time & S.G. & $\begin{array}{c}\text { Volume } \\
\text { (ml.) }\end{array}$ & $\begin{array}{c}\text { Chloride Concentration } \\
\text { (m.Eq./1.) }\end{array}$ & $\begin{array}{c}\text { Chlorides/Hour } \\
\text { (m.Eq.) }\end{array}$ \\
\hline $11-12$ noon & 1,006 & 118 & $21 \cdot 9$ & $2 \cdot 58$ \\
$12-1$ p.m. & 1,006 & 189 & $2 \cdot 43$ \\
$1-2$ p.m. & 1,006 & 162 & 19.8 & $3 \cdot 21$ \\
$2-3$ p.m. & 1,006 & 146 & $15 \cdot 6$ & $2 \cdot 27$ \\
\hline
\end{tabular}


Case 3. The third child, also a boy, did not suffer from diabetes insipidus or mental defect. When seen at 4 years of age he was in good health, except for slight talipes equino-varus.

Case 4. The fourth child (D.C.), again a boy, was born after surgical induction and weighed $8 \mathrm{lb} .8 \mathrm{oz}$. His mother had $\mathrm{Rh}$ antibodies up to $1 / 16$, but the baby had what appeared to be physiological jaundice, with normal serological tests, haemoglobin and serum bilirubin. Nevertheless he became anaemic and was given a blood transfusion at 3 months. At 4 months his haemoglobin level was $10 \cdot 5 \mathrm{~g} . \%$. He was early noted to be retarded. At 8 months he was admitted to Guy's Hospital. At the time he could not sit up. He was thought to have rickets but the biochemical and radiological findings did not support this. His urine was constantly of low specific gravity but was otherwise normal. His blood chemistry showed a raised urea with a high serum sodium content. On one occasion the blood phosphorus level was raised $(10.4 \mathrm{mg}$. \%), but later it was found to be normal. power improved also, and he was soon able to sit up, and later began to walk round his cot. A low-salt diet was tried for a short time in an effort to find some method of reducing his water requirement. However, he did not appear so well on this régime. When finally discharged at the age of 22 months he weighed $22 \mathrm{lb}$. He was followed up in the Out-patient Department and continued to gain weight. At the age of 26 months, he was tested again in the Department of Psychological Medicine. He had made definite progress but was still retarded. He was able to walk and could say a few single words. A year later he was re-tested and had made further progress, but was still not of normal intelligence. A fourth test was performed at the age of 4 years 3 months. On this occasion a formal assessment of his intelligence was attempted, and he was considered to have an I.Q. between 63 and 68 .

INVESTIGATIONS. These were the following:

At the age of 8 months an intravenous pyelogram showed poor concentration of dye.

Blood Chemistry. The following results were obtained:

\begin{tabular}{|c|c|c|c|c|c|c|}
\hline Age & $\begin{array}{c}\text { Blood } \\
\text { Urea } \\
\text { (mg. \%) }\end{array}$ & 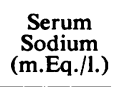 & $\begin{array}{l}\text { Serum } \\
\text { Chlorides } \\
\text { (m.Eq./I.) }\end{array}$ & $\underset{\substack{\text { Bicarbonate } \\
\text { (m.Eq./1.) }}}{\text { Plasma }}$ & $\begin{array}{l}\text { Serum } \\
\text { Potassium } \\
(\mathrm{m} . \mathrm{Eq} . / 1 .)\end{array}$ & $\begin{array}{c}\begin{array}{c}\text { Blood } \\
\text { Phosphorus } \\
\text { (mg. \%) }\end{array} \\
\text { (m. \% }\end{array}$ \\
\hline $\begin{array}{r}8 / 12 \\
\\
9 / 12 \\
14 / 12\end{array}$ & $\begin{array}{l}64 \\
80 \\
75 \\
51 \\
76 \\
53\end{array}$ & $\begin{array}{l}\overline{-} \\
\overline{172} \\
168 \\
\overline{175}\end{array}$ & $\begin{array}{l}\overline{-} \\
114 \\
120 \\
124 \\
115 \\
109\end{array}$ & $\begin{array}{l}- \\
- \\
29 \\
35 \\
31 \\
26\end{array}$ & $\begin{array}{l}\overline{5 \cdot 1} \\
4 \cdot 2\end{array}$ & $\begin{array}{r}10.4 \\
4.4 \\
-\end{array}$ \\
\hline
\end{tabular}

While in hospital he was given $35-45 \mathrm{oz}$. of fluid daily. At 14 months he was admitted to The Hospital for Sick Children for further investigation. On admission he was a pale, apathetic, dehydrated and wasted child who took little interest in his surroundings. He was unable to sit and muscle tone was poor. His weight was $13 \frac{1}{2} \mathrm{lb}$.
Urine. The specific gravity was never above 1,012, but otherwise the urine was normal, as was also the amino-acid pattern.

Renal Function Tests. At 9 months the urea clearance was as follows:

\begin{tabular}{c|c|c|c|c|c}
\hline \multirow{2}{*}{ Time } & \multicolumn{2}{|c|}{ Urine } & Blood Urea & $\begin{array}{c}\text { Urine Urea } \\
\text { (mg. \%) }\end{array}$ & Urea Clearance \\
\cline { 2 - 6 } & (vol. ml.) & ml./min. & 59 & 705 & $\begin{array}{c}28 \% \text { of average normal } \\
\text { (standard) } \\
\text { (standard) }\end{array}$ \\
\hline $1 \mathrm{hr}$. & 22 & 0.37 & 59 & 580 & $\begin{array}{c}22 \\
\text { (starmal normal }\end{array}$ \\
\hline
\end{tabular}

and height $26 \frac{1}{2}$ in. While in hospital he had breathholding attacks. He took fluids eagerly but was liable to vomit if given too much fluid at one time. At first he had a fever of $99^{\circ}$ to $100^{\circ}$, but when his fluid intake was adequate the temperature settled. During the seven weeks after his admission to hospital he gained $5 \frac{1}{2} \mathrm{lb}$., of which $2 \mathrm{lb}$. were in the first two weeks. His intake at this time was about $130 \mathrm{oz}$. daily and on occasions he took as much as $185 \mathrm{oz}$. in one day. While taking this large amount (he had not been having a very large intake at home) his condition began to improve. Slowly, he appeared brighter and began to look like a normal child. At 19 months he was tested and found to have a level of development of 9 to 10 months. His motor
Pitressin tests were performed three times.

(1) At 9 months, when the dose was 2 units at 11.30 a.m.

(2) At 15-18 months when the dose was 0.165 units at 3.45 p.m.

(3) The third test was done after a dose of 1.65 units at 12 noon, when the blood urea was $76 \mathrm{mg}$. \%.

(4) The dose was 0.08 units at 11.30 a.m.

(5) A fifth test was done using a control period after the injection of $1 \mathrm{ml}$. normal saline at 3.15 p.m., when blood urea was $46 \mathrm{mg}$. \%.

The fifth child was born after labour had been induced early because of the mother's antibodies, and died on the second day. At necropsy death was attributed to atelectasis. 
First pitressin test

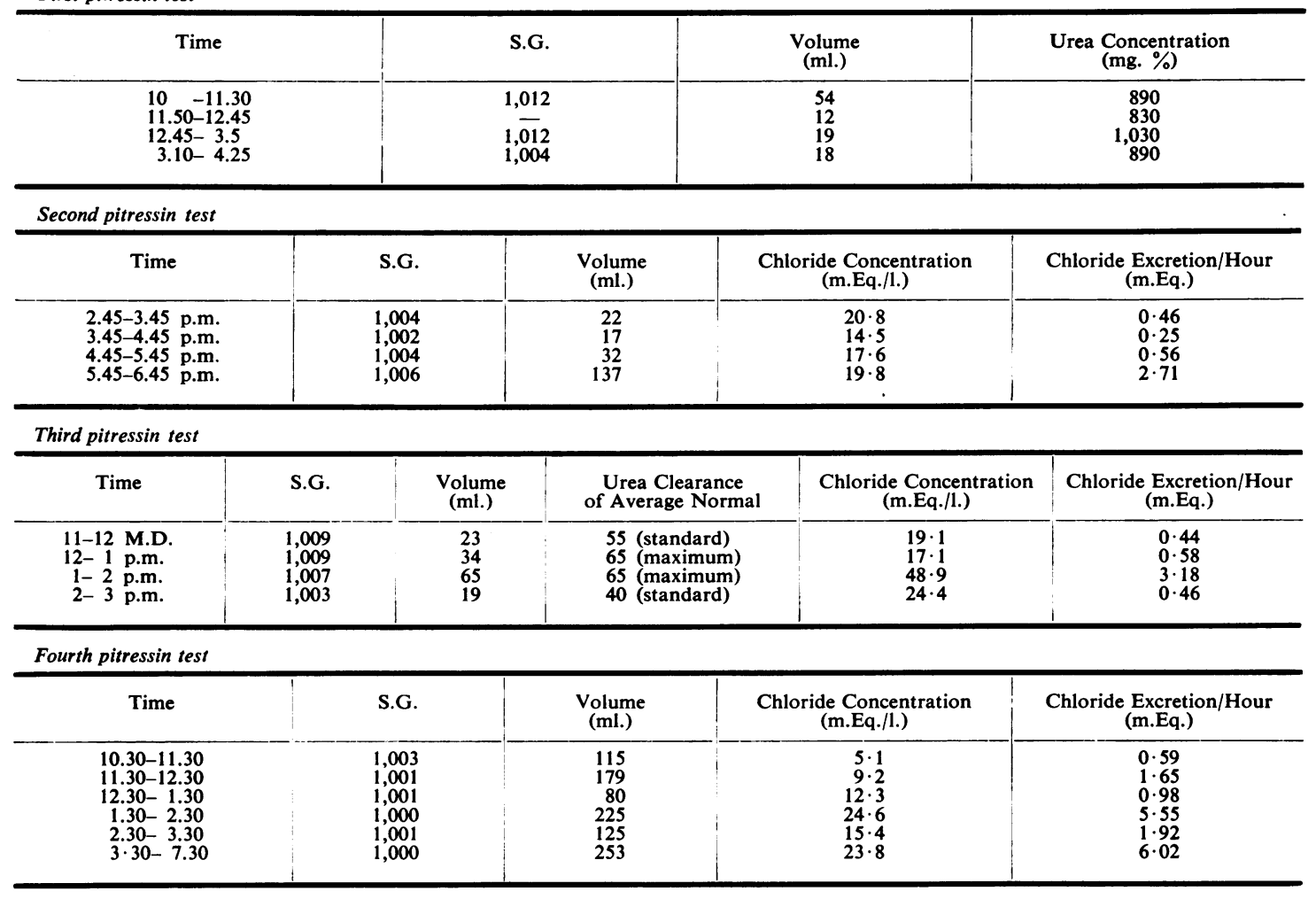

\begin{tabular}{|c|c|c|c|c|c|}
\hline Time & S.G. & $\begin{array}{l}\text { Volume } \\
\text { (ml.) }\end{array}$ & $\begin{array}{l}\text { Urea Clearance } \\
\text { (\% of normal) }\end{array}$ & $\begin{array}{l}\text { Chloride Concentration } \\
\text { (m.Eq./l.) }\end{array}$ & $\begin{array}{l}\text { Chloride Excretion/Hour } \\
\text { (m.Eq.) }\end{array}$ \\
\hline $\begin{array}{l}2.15-3.15 \text { p.m. } \\
3.15-4.15 \text { p.m. } \\
4.15-5.15 \text { p.m. } \\
5.15-6.15 \text { p.m. }\end{array}$ & $\begin{array}{l}1,002 \\
1,002 \\
1,002 \\
1,002\end{array}$ & $\begin{array}{l}110 \\
160 \\
118 \\
170\end{array}$ & 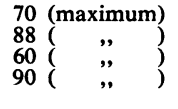 & $\begin{array}{l}10 \cdot 2 \\
11 \cdot 3 \\
14 \cdot 3 \\
11 \cdot 3\end{array}$ & $\begin{array}{l}1 \cdot 12 \\
1 \cdot 81 \\
1 \cdot 69 \\
1 \cdot 92\end{array}$ \\
\hline
\end{tabular}

\section{Discussion}

Interpretation of Renal Function Tests. Unfortunately no renal function tests were done on the first child (G.C.) and we know only that his blood urea was $40 \mathrm{mg} . \%$ on one occasion. In the two other children (E.C. and D.C.) described in this paper, a number of tests of renal function were performed.

In D.C. it was shown that the urine specific gravity rose only to 1,004 after 12 hours' fluid restriction, showing a serious defect in concentrating power. Since it was suspected that he had normal glomeruli, with a renal tubular defect for water reabsorption, it was decided to carry out a combined pitressin test and urea clearance. We considered that the slightly raised levels of blood urea obtained during the early investigation were a reflection of a reduced glomerular filtration rate secondary to dehydration. We therefore took care to supply abundant water during the tests. The injection of pitressin is purely a test of the ability of the renal tubule to react to circulating pitressin (A.D.H.) by a reduction in volume of urine, with a rise in specific gravity and a corresponding rise in the concentration of solutes, of which urea and chloride (as sodium chloride) are most conveniently measured. In general the results obtained with the pitressin test run more or less parallel to those obtained by the fluid restriction test, but the highest specific gravity obtained after the injection of pitressin is usually $1,015-1,020$ and is always less than the maximum specific gravity after 12 -hour fluid restriction. The reason for this difference between the results of the two tests is not known. As the kidney is extremely sensitive to pitressin a maximal response is obtained with very small doses. We have used water-soluble pitressin (Parke-Davis), which is almost free from 
the oxytocic factor, and which we found active in normal children in a dosage of 0.5 units per square metre of body surface area. This is much less than that recommended by Behrendt (1949) on the basis of the work of Sodeman and Engelhardt (1942) and Schneeberg, Likoff and Rubin (1943), but is twice the largest dose used by Heller (1944). Large doses may, in fact, give misleading results by interfering with glomerular filtration, and undesirable sideeffects such as pallor and slight hypertension may occur.

In doing this series of investigations we first used a dose calculated as described above and later used larger doses in order to eliminate the possibility of partial insensitivity. In conditions such as true diabetes insipidus and in the pitressin-resistant type, the urine passed during the control period (before the injection of pitressin) is bound to be low in specific gravity, and an unvarying flow can be obtained only by keeping the water load constant during the test. This was done by dividing the daily intake by 12 and giving this amount hourly. In the normal controls it is, of course, necessary to inhibit the production of endogenous pitressin (A.D.H.) by maintaining a similar water load throughout the test in order to demonstrate the effect of the injected pitressin.

\section{Results}

E.C. The first test with 0.25 units of pitressin, i.e., 0.5 units per sq. $\mathrm{m}$. surface area, has been compared to a similar test using the same scale of dosage on a child of the same age with normal kidneys. The difference between the two is very striking. Urea clearances were calculated from the data obtained during the first pitressin test and showed low normal figures. (The clearances are first calculated in absolute figures, then recalculated for a surface area of $1.73 \mathrm{sq} . \mathrm{m}$. and the figure obtained is then expressed as a percentage of a normal adult figure.) A second test with 10 times the original dose gave similar results. We considered that these results demonstrated that glomerular filtration was normal, but that the tubular response to pitressin was lacking.

D.C. His first urea clearance tests, done when he was 9 months old, gave the very low values which might be expected if he were slightly dehydrated; in support of this is the fact that his blood urea varied at this time between $59 \mathrm{mg} . \%$ and $80 \mathrm{mg}$. \%. Also the diagnosis had not been substantiated and he was being given inadequate amounts of water to drink. Similar difficulties arose in the interpretation of the first pitressin test, which was done during the same admission. The later pitressin tests, with smaller doses, were a little more satisfactory, but owing to inconstant water loads during the test the flow of urine obtained was very variable. Nevertheless, it was possible to demonstrate a failure of response to pitressin in three different doses. The most satisfactory of the tests, from the point of view of urine flow, was that performed with $1 \mathrm{ml}$. of normal saline to see whether the actual prick of the injection had any influence on the flow. We did this control test because it has been found that discomfort, such as is produced by catheterization, particularly in boys, causes a considerable reduction in urine flow for about one to two hours. However, the urine flow obtained during this last test was even, and the urea clearance was shown to be unequivocally normal. The pitressin test done on a standard dosage scale (dose: $0 \cdot 165$ units) has been compared (see graph) with a similar test performed in a child of the same age, with normal kidneys.

Both patients showed pyrexia when dehydrated, which has been commented upon previously (Waring et al., 1945; Luder and Burnett, 1954). Presumably this fever is analogous in some way to dehydration fever in infants, but the mechanism is not understood. The younger child (D.C.) also showed an undue liability, when compared with controls, to become pale even after small doses of pitressin. Such a sensitivity to the side-effects of pitressin was noted by Williams and Henry (1947) who thought that the kidney might not be destroying or fixing the pitressin as rapidly as usual.

The precise cause of the condition has not been fully worked out. The most likely alternatives are an anatomical defect in the region of the tubule responsible for water reabsorption, or an 'end-organ insensitivity'.

\section{Anatomical Defect}

Macdonald (1955) reported that micro-dissection of the kidneys of a $4 \frac{1}{2}$-month-old infant with this condition showed some diminution in the proximal tubular convolutions. The distal tubules and loops of Henle were normal in appearance and length. Darmady and Stranack (1954) dissected the tubules of one of another series of cases studied at Great Ormond Street. He reported no evidence of atrophy of the collecting or distal tubules. The proximal convoluted tubule seemed shorter than normal, but there appeared to be no abnormality of structure.

Although no abnormality has been detected in the structure of the tubule it is possible that the relation of the loops of Henle and the collecting tubules and their adjacent blood vessels in the renal medulla may be unusual as a congenital defect. 


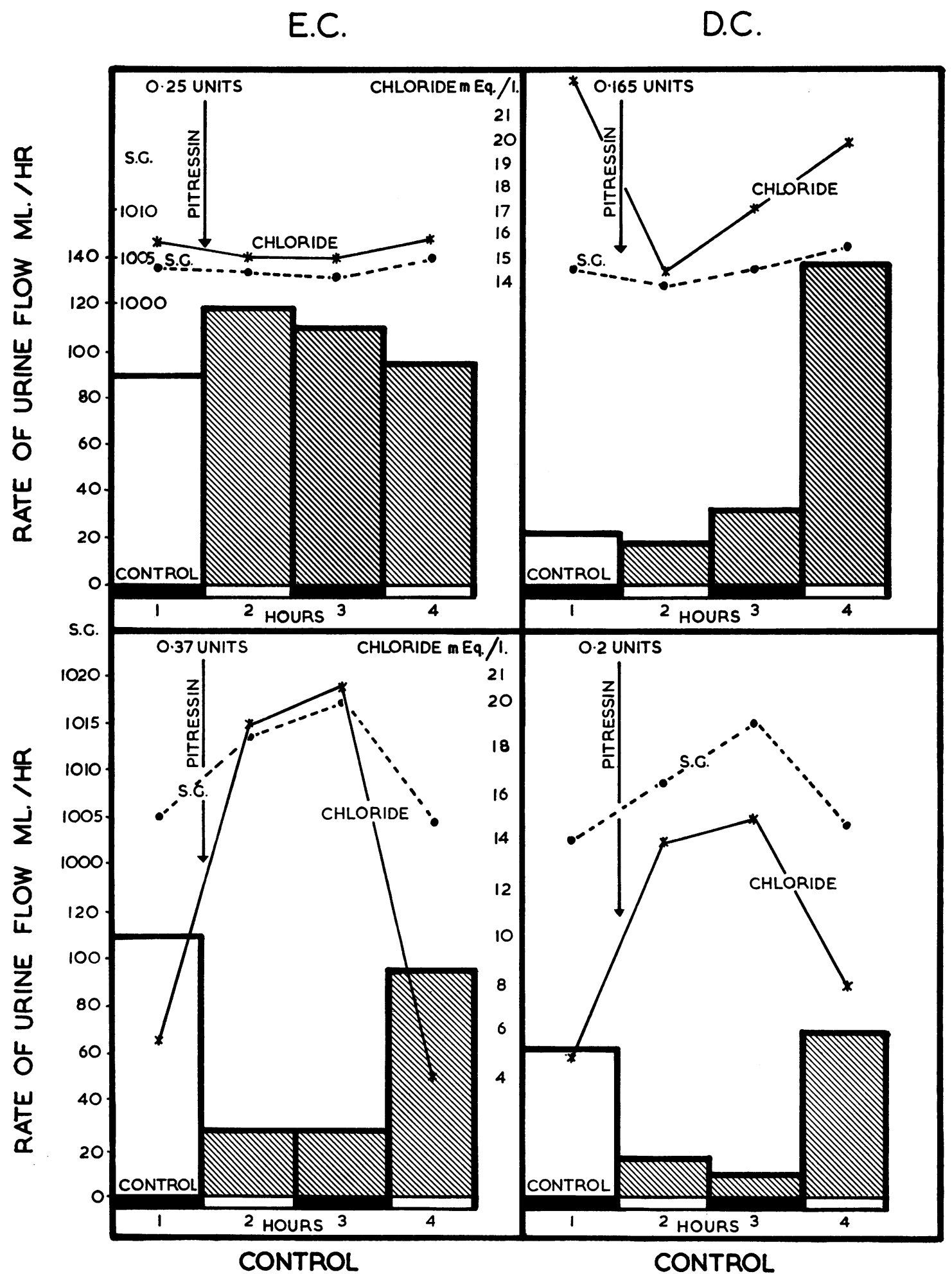

FIG. 1.-The effect of the standard dose of pitressin on the urine volume and concentration of patients E.C. and D.C. compared with normal controls. 
The importance of these relations is stressed by the work of Wirz, Hargitay and Kuhn (1951). They showed that in the golden hamster papillary blood vessels adjacent to the long loops of Henle contained hypertonic blood when the kidney was producing hypertonic urine. They suggested that the loop of Henle acts as an active hairpin counter current system, causing an increased concentration of solutes in the tip of the loop. These hypertonic media, which are some distance away from the convoluted tubules situated in the cortex, could cause passive transport of water from the urine in the collecting ducts which they adjoin and effect the final concentration of the urine. Thus, in the normal hamster, high osmotic pressures in the final urine can be achieved without the occurrence of high osmotic gradients, whereas in the patient with renal diabetes insipidus an anatomical abnormality might make concentration impossible. The relation of this mechanism to the action of A.D.H. is unknown.

'End-organ insensitivity' could be the explanation of the lack of action of A.D.H. if no anatomical defects were present and the hormone were present in adequate amounts in the blood stream.

At present it is not possible to decide which of these possibilities is the explanation of this disease.

\section{Treatment}

The treatment of these cases raises several interesting points. The consumption of large quantities of water during infancy, when the child is unable to regulate his own intake, makes the detailed instruction of the mother very important. Also the very large volumes of fluid required are liable to distend the stomach and impair the appetite for solids. It is necessary therefore to spread the fluid intake as evenly as possible during the day and if necessary during the night. The best guide to adequate hydration is the appearance of the child and his look of comfort or discomfort. Daily weighing is not very helpful as the weight is liable to violent fluctuations from day to day, but it is certain that more fluid is required if there is a persistent loss of weight. The rate at which rehydration of a new case should be attempted seems to depend upon each individual. Some observations (Wallace, 1953) have been made in cases similar to those demonstrated here which seem to show that it is better to proceed gradually with rehydration and not to attempt to bring the blood chemistry back to normal too rapidly. A too rapid rehydration may bring on symptoms akin to water-intoxication. This has been supposed to be due to a rapid change in the intracellular osmotic pressure, as the cells seem to take time to adapt to a new level of osmolarity.
Family and Sex Incidence

The familial incidence of pitressin-resistant diabetes insipidus is remarkable. In this family there was one healthy child, while two had the condition, another had an unidentified wasting disease, and the last died too young to show diabetes insipidus. Unfortunately, we do not know whether the great grandfather also had it.

Both the affected children were males and similar cases which have been previously reported have been male. Where members of more than one generation were affected (Williams and Henry, 1947; Forssman, 1945; Flax and Gersh, 1955) transmission was through the female as a dominant sex-linked characteristic. The condition is not necessarily fatal, some of the patients having reached adult life (Williams and Henry, 1947; Cates and Garrod, 1951), but no case of father-to-son transmission has yet been recorded. Although there is no proof, it is tempting to suppose that in our family the greatgrandfather did, in fact, have pitressin-resistant diabetes insipidus, and that some of his sons, all of whom died in infancy, also had it, while a surviving daughter passed it on to our patients.

\section{Mental Defect}

Our two patients were mentally defective, as was that described by Luder and Burnett (1954), while one member of the family described by Williams and Henry (1947) was retarded (he did not sit up until he was 1 year old) and had the disease. From records of other cases, it is clear that mental defect is not an essential accompaniment, but it is interesting to speculate whether in severe cases prolonged dehydration can produce it. In our cases we noted a close correlation between the mental state and the adequacy of the fluid supply. In Case 2 the experience of seeing this child alter when he was hydrated was inspiring, for it looked as though a baby who was almost an ament was being endowed with a mind, simply by being given a great deal of water. This improvement in the mental state is presumably largely due to the general increase in physical wellbeing which results in these patients when they are given adequate amounts to drink. Also when their thirst is unsatisfied their whole consciousness is preoccupied by a desire for fluids. This dehydrated state is further complicated by fever and infections to which they then seem peculiarly liable and which further reduce the energy available for mental activity.

Earlier optimism was somewhat modified by the lack of striking further mental development in these patients when fully hydrated. Case 1 has not developed more rapidly than the average imbecile of 
similar grade. From having a developmental quotient assessed at 31 on the Vineland scale and an I.Q. of 37 on the Merrill Palmer he scored some two and a half years later a D.Q. of 29 and an I.Q. of 31 on the Stanford Binet scale. Thus it would appear that in his case there is irreversible damage to the brain such as to give him the expectation of mental development of the unspecified imbecile.

\section{Summary}

Two brothers suffered from pitressin-resistant diabetes insipidus. Hydration improved them mentally and physically but did not make them normal. Investigation suggested that glomerular function was normal but that tubular response to pitressin was lacking. Difficulties in understanding, investigating and treating the condition are discussed.

We would like to thank many people for help in these cases over several years, particularly Dr. W. W. Payne for advice on chemical investigation, Dr. C. A. Holman and Dr. R. R. Race for blood grouping, Dr. D. A. Pond for electro-encephalography, Mrs. M. Marrs and Miss M. B. S. Durward for psychological reports, and the Department of Medical Illustration, The Hospital for Sick Children, Great Ormond Street, for the figure.

\section{REFERENCES}

Bailey, P. and Bremer, F, (1921). Arch, intern. Med., 28, 773. Behrendt, H. (1949). Diagnostic Tests for Infants and Children,

Cates, J. E. and Garrod, O. (1951). Clin. Sci., 10, 145.

Darmady, E. M. and Stranack, F. (1954). Personal communication. Flax, L. J. and Gersh, I. (1955). Amer. J. Dis. Child., 89, 602.

Forssman, H. (1945). Acta med. scand., Suppl. 159.

Heller, H. (1944).J. Physiol Lond $102,429$.

Luder, J. and Burnett, D. (1954). Archives of Disease in Childhood 29,44

Macdonald, W. B. (1955). Pediatrics, 15, 298

Schneeberg, H. G., Likoff, W. B. and Rubin, I. E. (1943). J. Lab. clin. Med., 28, 757.

Sodeman, W. A. and Engelhardt, H. T. (1942). Amer. J. med. Sci., $203,812$.

Wallace, W. M. (1953). Personal communication

Waring, A. J., Kajdi, L. and Tappan, V. (1945). Amer. J. Dis. Child., $69,323$.

Warkany, J. and Mitchell, A. G. (1939). Ibid., 57, 603.

Williams, R. H. and Henry, C. (1947). Ann. intern. Med., 27, 84.

Wirz, H., Hargitay, B. and Kuhn, W. (1951). Helv. physiol. pharmacol. Acta, 9, 196. 